\title{
Effect of Anti-Microbial Materials on Storages of Ssamjang
}

\author{
Bo-Ra Kang • Go-Eun Im • Dong-Han Kim* \\ 항균물질 첨가에 의한 쌈장의 저장중 품질특성
}

강보라 · 임고은 · 김동한*

Received: 29 June 2012 / Accepted: 13 December 2012 / Published Online: 31 March 2013

(C) The Korean Society for Applied Biological Chemistry 2013

\begin{abstract}
The effect of additives on the quality of ssamjang was investigated during storage. The L-, a- and b-values of ssamjang decreased gradually during storage, and the total color difference $(\Delta \mathrm{E})$ increased in the control group. The gas production of ssamjang was reduced in K-sorbate, alcohol and mustard added groups. The number of yeast increased rapidly up to 6 weeks of storage, then decreased in the mustard, alcohol, and K-sorbate added groups. The oxidation-reduction potential and water activity decreased until 6 weeks and 12 weeks, respectively, and then increased gradually. Titratable acidity increased with concomitant decrease in $\mathrm{pH}$, however, it increased slightly in the K-sorbate and ethanol added groups. Reducing sugar content increased until 9 weeks of storage, except the turmeric added group. Alcohol content increased until 15 weeks in the Japanese apricot juice, and turmeric added group. The sensory test result for the taste, flavor and overall acceptability showed that mustard added ssamjang was more acceptable than other groups.
\end{abstract}

Keywords microflora $\cdot$ physicochemical properties $\cdot$ ssamjang $\cdot$ storage

\section{서 론}

쌈장은 막장이나 된장에 고추장이나 마늘, 생강, 후추, 참기름

B.-R. Kang $\cdot$ G.-E. Im $\cdot$ D.-H. Kim

Department of Food \& Nutrition, Mokpo National University, Muan, Jeonnam 534-729, Republic of Korea

*Corresponding author (D.-H. Kim: dhankim@mokpo.ac.kr)
등의 양념류를 가미하여 제조하는 일종의 가공 된장으로, 식품 공전에서는 장류 식품중 혼합장으로 구분하고 있다. 쌈이 우리 나라에 전래된 경위와 연대는 확실하지 않지만 고려시대에 쌈 의 방식이 중국의 원나라로부터 전래된 것으로 추정되고 있다 (Kang, 1986). 쌈장은 주로 가정에서 전통적으로 이용하여 왔던 방법이 전래되어 왔으나 최근에 제조방법의 표준화 및 저장중 의 품질에 관한 연구가 시도되고 있다(Kim 등, 1998a; 1999a). 된장이 대두를 주원료로 하는 발효식품으로 곡류 위주의 식생 활에서 부족되기 쉬운 단백질 함량이 높아 영양적으로 우수한 조미식품이라면, 쌈장은 외식산업의 발달, 육류와 채소의 소비 증가, 식생활의 편의성 추구 등 시대적 변화에 의하여 급속하 게 산업적으로 대량 생산되고 있는 제품이다. 그러나 쌈장은 다 른 장류와는 달리 그 제조방법의 과학화와 품질의 표준화를 위 한 연구는 미미한 실정으로 쌈장의 품질향상을 위여 Lee 등 (2001)은 매실즙을 $6 \%$ 첨가하거나 마늘, 생강 등 부재료로 사 용하였다. 보통 쌈장은 부재료의 첨가로 염도가 낮아 일반 장 류와는 달리 보존 중에 관능적, 이화학적인 품질 특성 유지가 어려워 유통에 제한요소가 되며, 다양한 제품개발을 어렵게 하 는 요인이 되고 있다(Kim 등, 2000a). 상업적으로 생산되는 쌈 장 등 장류는 보존중 품질유지를 위해서 보존료로 K-sorbate를 $0.1 \%$ 이하를 사용 $(\mathrm{Seo}$ 등, 2001)하고 있으나 소비자의 거부감 때문에 $4 \%$ 이하의 알코올을 첨가하거나 가열살균처리, $1 \%$ 이 하의 겨자 등 항균성 부원료 첨가, 저온유통 등을 병용하는 방 법(Kim 등, 2005a; 2005b; Han과 Kim, 2008)이 시도되고 있 다. 또한 쌈장도 고추장이나 된장처럼 유통 중에 변색(Kim, 1996 ; Kwak과 Lim, 2003)과 가스발생(Kim 등, 1999b)이 상품 성을 떨어뜨리는 중요한 요인이 되고 있다.

이에 본 연구에서는 쌈장의 저장성과 품질향상을 위하여 일 반 공장에서 상업적으로 제조하는 쌈장의 제조방법을 기본으로 하고 항균활성이 있는 K-sorbate와 알코올, 겨자와 기호도 향상 을 위하여 매실즙과 울금을 부원료로 첨가하여 쌈장을 제조하 고 관능평가와 저장중의 이화학적 품질 특성을 비교 검토하였다. 


\section{재료 및 방법}

재료. 쌈장 제조에 사용한 된장과 고추장은 토박이순창식품(주) 에서 제조한 제품을, 물엿(맥아당 $55 \%$ ), 멸치다시다, 참기름, 후 추(흑후주 $100 \%)$ 와 마늘, 참깨, 생강, 양파는 시중 마트에서 구 입하여 사용하였다. 또한 쌈장에 추가한 항균성 부원료로 알코 올(Baker, Holland), K-sorbate (Yakuri pure Chem., Japan), 분말겨자, 매실과즙(과즙 $50 \%$ )을 사용하였고, 울금 분말은 전북 농업기술원에서 분양 받아 사용하였다.

쌈장의 제조. 쌈장의 제조는 된장 $65 \%$, 고추장 $18 \%$, 물엿 $12.25 \%$ 를 기본 주재료로 하고 여기에 부재료로 멸치다시다 $0.25 \%$, 참기름 $0.5 \%$, 참깨소금 $0.5 \%$, 마늘 $3 \%$, 후추 $0.1 \%$, 생 강 $0.25 \%$, 양파를 $0.15 \%$ 되게 혼합 첨가하여 제조한 쌈장을 대 조구로 하였다. 시험구별로는 대조구 쌈장에 Table 1 과 같이 항 균성물질로 K-sorbate $0.08 \%(\mathrm{Seo}$ 등, 2001), 알코올 3.5\%, 겨자 $1 \%(\mathrm{Kim}$ 등, $2005 \mathrm{~b}$; Han과 $\mathrm{Kim}, 2008)$ 를, 기호도 향상을 위하 여 매실과즙 4\%(Lee 등, 2001)와 울금 $0.1 \%$ (Choi 등, 2009)를 구분하여 첨가하였으며, 시판 쌈장은 토박이 순창식품(주) 제품을 사용하였다.

쌈장의 포장 및 저장. 쌈장의 포장은 각 시험구별로 복합필름 으로 된 포장대(PET; $19 \mu \mathrm{m} / \mathrm{CPP} ; 80 \mu \mathrm{m}$, 내부 크기; $90 \mathrm{~mm}$ $\times 120 \mathrm{~mm}$ )에 $150 \mathrm{~g}$ 씩 넣어 밀봉하였다. 쌈장의 저장은 시험구 별로 각각 $30^{\circ} \mathrm{C}$ 에서 18 주간 저장하였다.

가스발생량. 쌈장 저장 중 생성되는 가스는 밀봉된 시료의 팽 창에 따라 포장대의 실리콘이 부착된 부위에서 주사기로 가스 를 뽑아내고 그 용량을 합하여 가스 발생 총량으로 하였다 $(\mathrm{Kim}$ 등, 2000b).

일반성분. 쌈장의 $\mathrm{pH}$ 와 적정산도, 환원당, 알코올, 아미노산성 질소, 암모니아성 질소 함량은 기준미증분석법(Institute of Miso Technologists, 1968)에 준하여 측정하였다.

수분활성도와 색도, 산화환원전위. 수분활성도는 Rotronic ag hygroskop (BT-RS1, Swiss)로, 색도는 색차계(Chromameter CR-200, Minolta, Japan)로 측정하여 L (lightness), a (redness), $\mathrm{b}$ (yellowness 값과 $\Delta \mathrm{E}=[(\mathrm{L} 0-\mathrm{L} 1) 2+(\mathrm{a} 0-\mathrm{a} 1) 2+(\mathrm{b} 0-\mathrm{b} 1) 2]^{1 / 2}$ 값을 Hunter scale로 표시하였다. 산화환원전위(ORP)는 쌈장을 2배 희석한 후 ORP-meter (Onion 525A+, Orion, USA)를 이용하 여 직접 측정하였다.

생균수. 쌈장의 생균수는 호기성 세균은 tryptic soy agar (Thomas 등, 1981), 통성 혐기성 세균은 APT agar (Difco Lab., 1984) 를 사용하여 평판도말 한 후 $1.5 \%$ agar를 덮어 중층 하였고,
효모는 rose bengal agar 배지(Martin, 1965)를 사용하여 평판도 말법으로 $28^{\circ} \mathrm{C}$ 에서 $1-3$ 일간 배양한 후 계수 하였다.

관능검사. 혼합 제조한 쌈장을 20 명의 식품영양학과 학생들을 대상으로 맛, 향기, 색깔과 종합적인 기호도를 최고 7점 최저 1 점으로 7단계 평가하여 얻은 성적을 SAS package로 분산분석 을 하고 Duncan's multiple range test에 의해 통계 처리하였다.

\section{결과 및 고찰}

색도. 쌈장의 색도 변화를 Hunter scale로 측정한 결과는 Table 2 와 같이 L-과 a-, b-값 모두 저장 6주까지 급격히 저하되었고 그 이후에는 서서히 감소하였다 $(p<0.05)$. 시험구간에는 저장 초 기에는 대조구와 울금, 겨자 첨가구에서 $\mathrm{L}$-과 $\mathrm{a}-$, b-값이 높았 으나 저장 후기에는 다른 시험구와 유사하였으며, 시판 제품은 가열살균 처리에 의한 갈변으로 L-과 a-, b-값이 낮은 수준이었 다. 한편 된장의 경우 저장 중 $\mathrm{L}$-과 $\mathrm{a}-\mathrm{b}$-값 모두 $15^{\circ} \mathrm{C}$ 보다 $30^{\circ} \mathrm{C}$ 에서 변화가 심하였으며 가열살균 처리하지 않은 경우 Maillard 반응보다는 효소적 갈변반응인 tyrosinase의 작용에 의 한 L-dihydroxy phenyl alanine (L-DOPA)가 흑갈색인 melanin 을 생성하였다고 보고(Kim 등, 1999b)하였다.

Total color difference인 $\Delta \mathrm{E}$ 값의 변화는 Fig. 1과 같이 대조 구와 울금 첨가구에서 심하였다. 그러나 시판 쌈장의 경우 저 장 초기의 L-, a-, b-값이 다른 시험구에 비하여 낮았기 때문에 저장 중에 $\Delta \mathrm{E}$ 값의 변화는 상대적으로 적었다. $\mathrm{Kim}$ 등(2005a) 은 쌈장의 표면색도는 저장기간이 경과함에 따라 L-과 a-, b-값 의 저하로 $\Delta \mathrm{E}$ 값은 증가되었으며, 표면색도에 영항을 미치는 주 요인자는 살균온도보다 저장온도의 영향이 큰 것으로 보고하였 다. 한편 된장의 갈변은 온도와 산소, 금속, 광선의 영향을 받 으며, 갈변을 억제하려면 $20^{\circ} \mathrm{C}$ 이하의 온도에서 산소와 접촉을 최대한 억제하고 $\mathrm{Fe}$ 같은 금속의 혼입을 최소화시키는 관리가 필요한 것으로 보고(Kwon 등, 1998)된 바 있다.

가스발생. 쌈장 저장 중에 포장용기 내에서 부피 팽창을 유발 하는 가스 발생은 Table 3 과 같이 매실즙과 울금을 첨가한 경 우 무첨가구인 대조구보다 가스발생이 심하였으나 K-sorbate와 알코올, 겨자 첨가로 억제되었다 $(p<0.05)$. 반면 상업적으로 생 산되는 시판 쌈장도 보존료 첨가와 가열살균 처리를 병용하였 기 때문에 가스 생성은 없었다. 이러한 결과는 고추장에서 생 성된 가스의 $80 \%$ 이상이 $\mathrm{CO}_{2}$ 이며, 알코올이나 마늘, K-sorbate, 겨자를 첨가하거나 저온살균처리 $\left(60^{\circ} \mathrm{C}, 15 \mathrm{~min}\right)$ 를 하면 저장 중

Table 1 Mixing ratio of raw materials for preparation of ssamjang

\begin{tabular}{lccccccc}
\hline & Control & K & E & M & A & T & C \\
\hline Doenjang & 3250 & 3250 & 3250 & 3250 & 3250 & 3250 & - \\
Kochujang & 900 & 900 & 900 & 900 & 900 & 900 & - \\
Starch syrup & 612.5 & 612.5 & 612.5 & 612.5 & 612.5 & 612.5 & - \\
Sub-material & 237.5 & 237.5 & 237.5 & 237.5 & 237.5 & 237.5 & - \\
K-sorbate & - & 4 & - & - & - & - & - \\
Ethanol & - & - & 175 & - & - & - & - \\
Mustard & - & - & - & 50 & - & - & - \\
Japanese apricot & - & - & - & - & 200 & - & - \\
Turmeric & - & - & - & - & - & 5
\end{tabular}

K: K-sorbate added ssamjang, E: ethanol added ssamjang, M: mustard added ssamjang, A: Japanese apricot added ssamjang, U: Turmeric added ssamjang, C: commercial ssamjang 
Table 2 Changes in color values of ssamjang during storage at $30^{\circ} \mathrm{C}$

\begin{tabular}{|c|c|c|c|c|c|}
\hline \multirow{2}{*}{$\begin{array}{c}\text { Hunter } \\
\text { color value }\end{array}$} & \multirow{2}{*}{ Ssamjang } & \multicolumn{4}{|c|}{ Storage time (weeks) } \\
\hline & & 0 & 6 & 12 & 18 \\
\hline \multirow{7}{*}{$\mathrm{L}$} & Control & $37.61 \pm 0.40^{\mathrm{a})}$ & $27.48 \pm 0.39^{\text {b) }}$ & $23.25 \pm 0.22^{\mathrm{c})}$ & $20.48 \pm 0.44^{\mathrm{d})}$ \\
\hline & $\mathrm{K}$ & $36.70 \pm 0.44^{\mathrm{a})}$ & $26.93 \pm 0.48^{b)}$ & $24.23 \pm 0.33^{\mathrm{c})}$ & $\left.21.13 \pm 0.29^{d}\right)$ \\
\hline & $\mathrm{E}$ & $36.26 \pm 0.46^{\mathrm{a})}$ & $27.38 \pm 0.40^{\mathrm{b})}$ & $24.46 \pm 0.29^{\mathrm{c})}$ & $20.55 \pm 0.37^{\mathrm{d})}$ \\
\hline & M & $37.74 \pm 0.38^{a)}$ & $28.86 \pm 0.37^{b)}$ & $25.09 \pm 0.60^{\mathrm{c})}$ & $20.71 \pm 0.26^{\mathrm{d})}$ \\
\hline & A & $36.49 \pm 0.52^{\mathrm{a})}$ & $29.01 \pm 0.39^{\mathrm{b})}$ & $24.54 \pm 0.32^{\mathrm{c})}$ & $20.30 \pm 0.52^{\mathrm{d})}$ \\
\hline & $\mathrm{T}$ & $38.00 \pm 0.47^{\mathrm{a})}$ & $29.14 \pm 0.39^{\mathrm{b})}$ & $24.48 \pm 0.38^{\mathrm{c})}$ & $20.16 \pm 0.30^{d)}$ \\
\hline & $\mathrm{C}$ & $34.79 \pm 0.42^{\mathrm{a})}$ & $26.76 \pm 0.51^{b)}$ & $23.67 \pm 0.37^{\mathrm{c})}$ & $19.97 \pm 0.19^{\mathrm{d})}$ \\
\hline \multirow{7}{*}{$\mathrm{a}$} & Control & $19.05 \pm 0.25^{\mathrm{a})}$ & $12.36 \pm 0.37^{\mathrm{b})}$ & $8.34 \pm 0.47^{\mathrm{c})}$ & $8.74 \pm 0.29^{c)}$ \\
\hline & $\mathrm{K}$ & $18.43 \pm 0.26^{\mathrm{a})}$ & $10.86 \pm 0.25^{\mathrm{b})}$ & $9.37 \pm 0.16^{\mathrm{c})}$ & $9.36 \pm 0.36^{\mathrm{c})}$ \\
\hline & $\mathrm{E}$ & $19.11 \pm 0.45^{\mathrm{a})}$ & $11.42 \pm 0.43^{\mathrm{b})}$ & $\left.8.96 \pm 0.28^{\mathrm{c}}\right)$ & $9.37 \pm 0.49^{\mathrm{c})}$ \\
\hline & M & $18.84 \pm 0.53^{\mathrm{a})}$ & $12.65 \pm 0.52^{b)}$ & $8.96 \pm 0.54^{\mathrm{c})}$ & $9.68 \pm 0.43^{\mathrm{c})}$ \\
\hline & A & $18.85 \pm 0.15^{\mathrm{a})}$ & $13.96 \pm 0.40^{\mathrm{b})}$ & $9.49 \pm 0.26^{\mathrm{c})}$ & $9.39 \pm 0.21^{\mathrm{c})}$ \\
\hline & $\mathrm{T}$ & $18.93 \pm 0.42^{\mathrm{a})}$ & $13.82 \pm 0.31^{\mathrm{b})}$ & $8.92 \pm 0.51^{\mathrm{c})}$ & $8.78 \pm 0.13^{\mathrm{c})}$ \\
\hline & $\mathrm{C}$ & $18.43 \pm 0.38^{a)}$ & $10.59 \pm 0.32^{b)}$ & $8.40 \pm 0.22^{\mathrm{c})}$ & $8.42 \pm 0.32^{\mathrm{c})}$ \\
\hline \multirow{7}{*}{$b$} & Control & $25.03 \pm 0.59^{\mathrm{a})}$ & $12.71 \pm 0.20^{\mathrm{b})}$ & $\left.9.26 \pm 0.29^{c}\right)$ & $6.40 \pm 0.24^{\mathrm{d})}$ \\
\hline & K & $23.36 \pm 0.31^{a)}$ & $12.30 \pm 0.41^{\mathrm{b})}$ & $\left.9.90 \pm 0.28^{c}\right)$ & $6.73 \pm 0.26^{\mathrm{d})}$ \\
\hline & $\mathrm{E}$ & $24.16 \pm 0.42^{a)}$ & $12.96 \pm 0.21^{b)}$ & $10.27 \pm 0.39^{\mathrm{c})}$ & $6.21 \pm 0.41^{\mathrm{d})}$ \\
\hline & M & $25.34 \pm 0.23^{a)}$ & $13.67 \pm 0.27^{b)}$ & $10.71 \pm 0.17^{\mathrm{c})}$ & $7.01 \pm 0.35^{\mathrm{d})}$ \\
\hline & A & $24.09 \pm 0.41^{\mathrm{a})}$ & $13.10 \pm 0.26^{\mathrm{b})}$ & $10.36 \pm 0.21^{\mathrm{c})}$ & $6.54 \pm 0.22^{\mathrm{d})}$ \\
\hline & $\mathrm{T}$ & $24.69 \pm 0.49^{\mathrm{a})}$ & $13.96 \pm 0.30^{\mathrm{b})}$ & $9.89 \pm 0.40^{\mathrm{c})}$ & $6.54 \pm 0.32^{\mathrm{d})}$ \\
\hline & $\mathrm{C}$ & $22.43 \pm 0.34^{\mathrm{a})}$ & $11.88 \pm 0.37^{\mathrm{b})}$ & $\left.8.98 \pm 0.29^{c}\right)$ & $5.88 \pm 0.11^{\mathrm{d})}$ \\
\hline
\end{tabular}

${ }^{1)}$ See footnotes in Table 1.

${ }^{2)}$ Values are mean $\pm \mathrm{SD}$

${ }^{3}$ Means with the same letter in row are not significantly different by Duncans multiple range test $(p<0.05)$

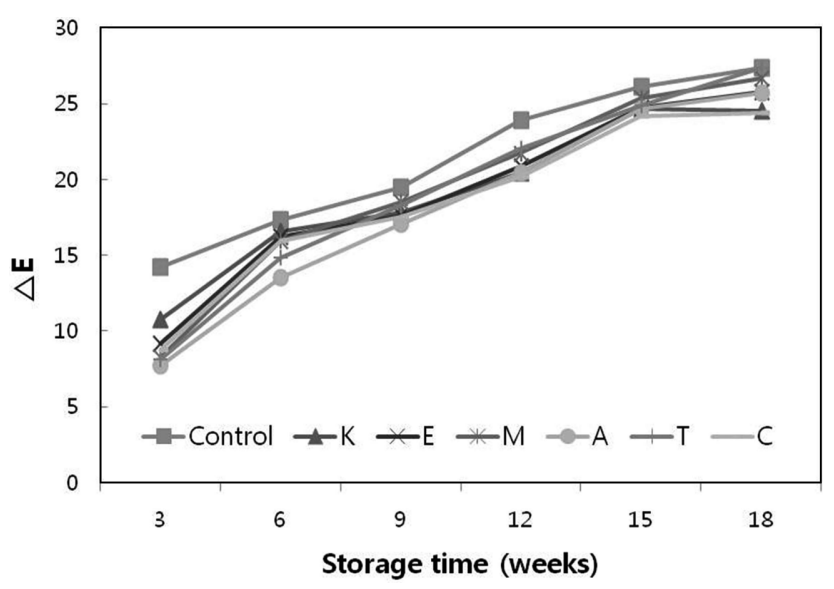

Fig. 1 Changes in color difference value of ssamjang during storage at $30^{\circ} \mathrm{C}$.

에 가스 생성을 효과적으로 억제할 수 있었던 Kim 등(1998b) 와 $\mathrm{Kim}$ 과 $\mathrm{Kwon}(2001)$ 의 보고와 유사한 경향이었다. 한편 장 류에서의 $\mathrm{CO}_{2}$ 생성은 주로 Zygosaccharomyces rouxii, Saccharomyces cerevisiae, Candida versatilis, C. etchellsii와 같은 내염성 효모의 생장에 기인하며, 이들 효모는 숙성 후기 에 감소하지만 배합, 충전, 포장 공정에서 새로운 환경이 조성 되면 다시 번식하고 된장보다 당 함량 높은 고추장에서 많이 발생되는 것으로 보고 $(\mathrm{Kim}$ 등, 2000b)된 바 있다.
미생물 변화. 쌈장의 저장중 미생물수 변화는 Fig. 2에서 보는 바와 같이 효모의 경우 저장 6 주에 급격히 증가하였으나 12 주 후에는 감소하였다. 시험구간에는 겨자와 알코올, K-sorbate 첨 가구에서 효모수의 증가가 적었고 매실즙과 울금 첨가구에서 많 아 이들 첨가구에서 효모수의 증가가 저장중 가스 생성의 직접 적인 원인이 되었다. 한편 효모수가 $10^{4} \mathrm{CFU} / \mathrm{g}$ 이상으로 증식 될 때 포장용기 내부의 swelling 개시 시점이 된다는 Kim 등 (2000a)의 보고와 Table 3 의 가스 발생 결과와는 다소 차이가 있어 가스발생은 효모수 보다는 효모 종류의 영향이 큰 것으로 판단되었다(Kim과 Kwon, 2001). 호기성 세균과 혐기성 세균은 저장 중에 불규칙한 증감을 보였으나 효모수와는 달리 세균수 의 변화는 적었다. 시험구간에는 큰 차이는 없었으나 K-sorbate 첨가구에서 세균수가 조금 적었으며 효모수가 적었던 알코올과 겨자의 첨가 효과는 볼 수 없었고 시판 쌈장에서 조금 많은 수 준이었다. 한편 포장된 전통 된장과 고추장의 경우 저장 100 일 동안 호기성 세균과 젖산균은 뚜렷한 변화가 없었던 결과 $(\mathrm{Kim}$ 등, $2000 \mathrm{~b}$ )와 본 실험은 유사하였으나, 초고추장에 솔잎이나 약 쑥 추출물 $1-10 \%$ 첨가시 총균수는 저장 21 일까지 감소되었던 보고(Kim과 Kang, 2007)와는 다소 상이하였다.

산화환원전위와 수분활성도. 쌈장 저장 중 미생물의 생육과 밀 접한 관계가 있는 산화환원전위(ORP)는 Fig. 3과 같이 저장 6 주까지 저하되었으나 그 이후에는 서서히 증가하는 경향을 보 였으며, 시판 쌈장과 울금 첨가구에서 조금 낮은 경향이었다. 이러한 결과는 항균물질을 혼합 첨가한 저식염 고추장(Han과 $\mathrm{Kim}, 2008$ )에서 $\mathrm{ORP}$ 가 저장 4주경에 $-75.3 \sim-93.3 \mathrm{mV}$ 로 증가 하나 그 이후에는 저하되어 12주에 $-204.0 \sim-214.3 \mathrm{mV}$ 로 저하 

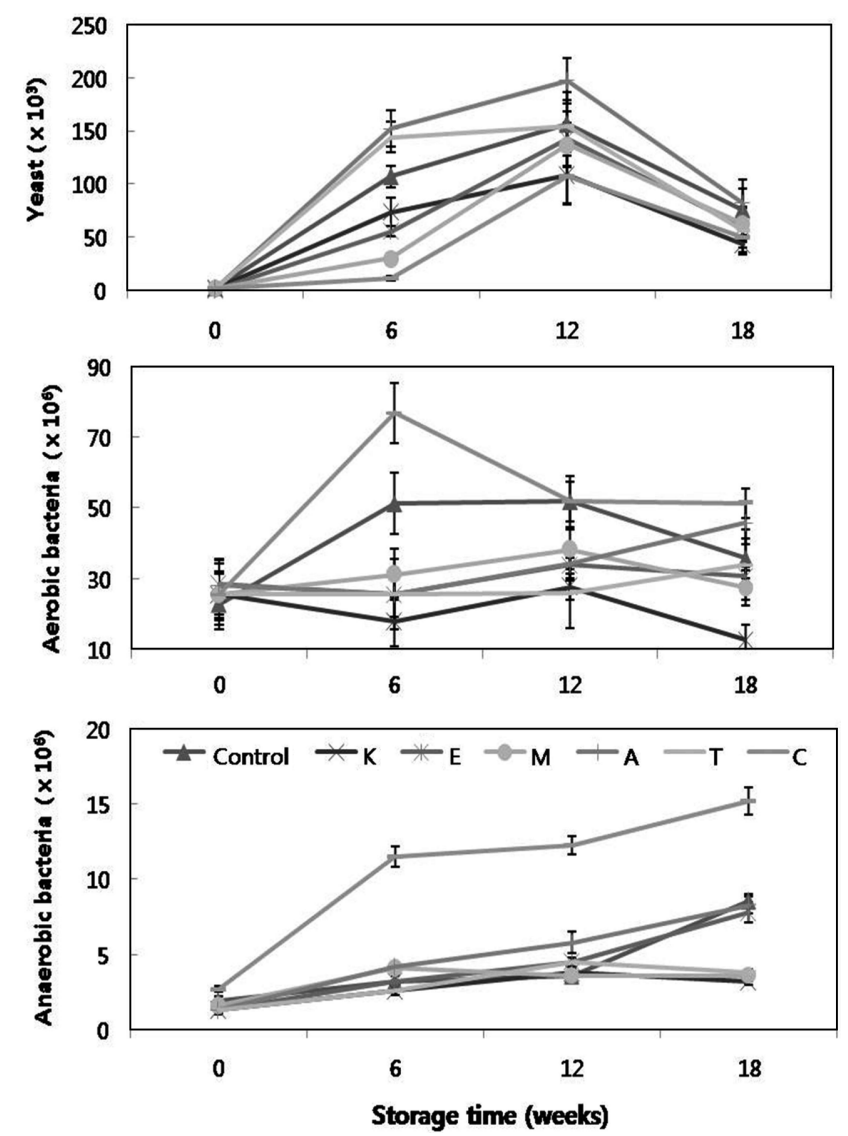

Fig. 2 Changes in viable cell counts of microorganism of ssamjang during storage at $30^{\circ} \mathrm{C}$.

되었던 보고와는 차이가 있었다. 한편 ORP가 호기성균의 증식 이 억제되고 혐기성 세균의 증식에 유리한 환경이 되는 -200 $\mathrm{mV}$ 이하(James, 2000)는 울금 첨가구와 시판 쌈장에서 저장 6 주 부근뿐이어서 쌈장의 산화환원전위가 호기성 세균의 증식을 조절하는 수준은 아니었다.

수분활성도(Fig. 4)는 저장 중에 수분이 증가하였음에도 불구 하고 저장 12 주까지 저하하다가 이후 근소한 증가를 보였는데 이는 저장 12 주까지는 쌈장의 원료성분이 분해되어 용질의 몰

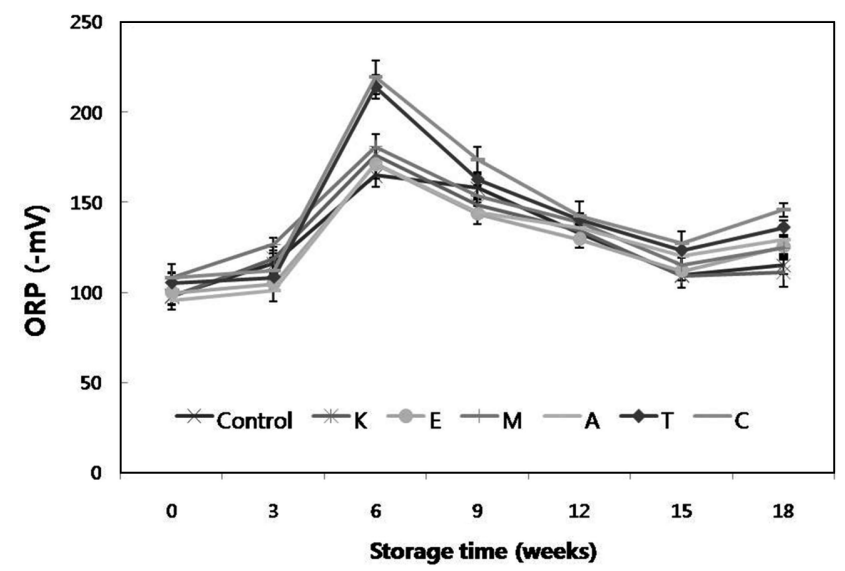

Fig. 3 Changes in oxidation-reduction potential of ssamjang during storage at $30^{\circ} \mathrm{C}$.

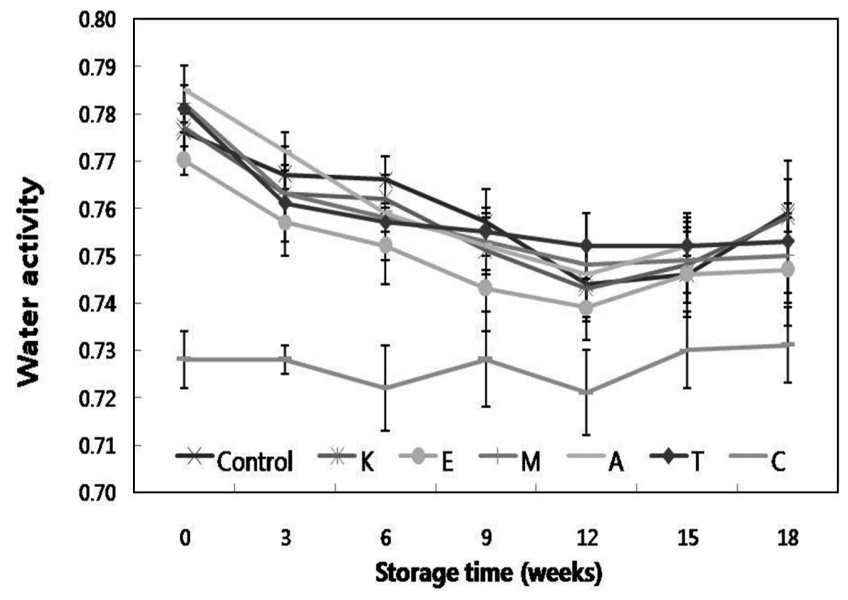

Fig. 4 Changes in water activities of ssamjang during storage at $30^{\circ} \mathrm{C}$.

분율이 증가하였기 때문인 것으로 판단되었다. 이러한 결과는 쌈장을 $60-70^{\circ} \mathrm{C}$ 에서 20 분간 살균한 경우 수분은 저장 기간 중 불규칙한 증감을 보였고( $\mathrm{Kim}$ 등, 2005b), 수분활성도는 저장 10 주까지 증가되었던 보고( $\mathrm{Kim}$ 등, 2005a)와 다소 차이가 있었다. $\mathrm{pH}$ 와 적정산도. 쌈장 저장중 $\mathrm{pH}$ 의 변화는 Fig. 5 와 같이 저장

Table 3 Changes in gas production of ssamjang during storage at $30^{\circ} \mathrm{C}$

(Unit: $\mathrm{mL} / 150 \mathrm{~g}$ )

\begin{tabular}{ccccccccc}
\hline \multirow{2}{*}{ Ssamjang } & \multicolumn{7}{c}{ Storage time (weeks) } \\
\cline { 2 - 7 } & 2 & 4 & 6 & 8 & 10 & 12 & 18 \\
\hline Control & - & - & $48.5 \pm 2.1^{\mathrm{aC}}$ & $150.7 \pm 10.1^{\mathrm{bB}}$ & $91.5 \pm 14.4^{\mathrm{cA}}$ & - & - & $290.7 \pm 35.9$ \\
K & - & - & - & - & - & - & - \\
E & - & - & - & - & - & - & - \\
M & - & - & & - & - & - & - & - \\
A & - & $15.1 \pm 0.85^{\mathrm{c})}$ & $866.7 \pm 47.7^{\mathrm{aA}}$ & $267.1 \pm 12.8^{\mathrm{bA}}$ & $4.1 \pm 1.4^{\mathrm{cB}}$ & - & - & $1153.0 \pm 63.9$ \\
T & - & - & $429.8 \pm 19.9^{\mathrm{aB}}$ & $288.7 \pm 27.6^{\mathrm{bA}}$ & $13.4 \pm 1.9^{\mathrm{cB}}$ & - & - & $731.9 \pm 26.7$ \\
C & - & - & - & - & - & - & - & - \\
\hline
\end{tabular}

${ }^{1)}$ See footnotes in Table 1.

${ }^{2)}$ Values are mean \pm SD

${ }^{3}$ Means with the same letter in row are not significantly different by Duncans multiple range test $(p<0.05)$

${ }^{4}$ Means with the same letter in column are not significantly different by Duncans multiple range test $(p<0.05)$ 

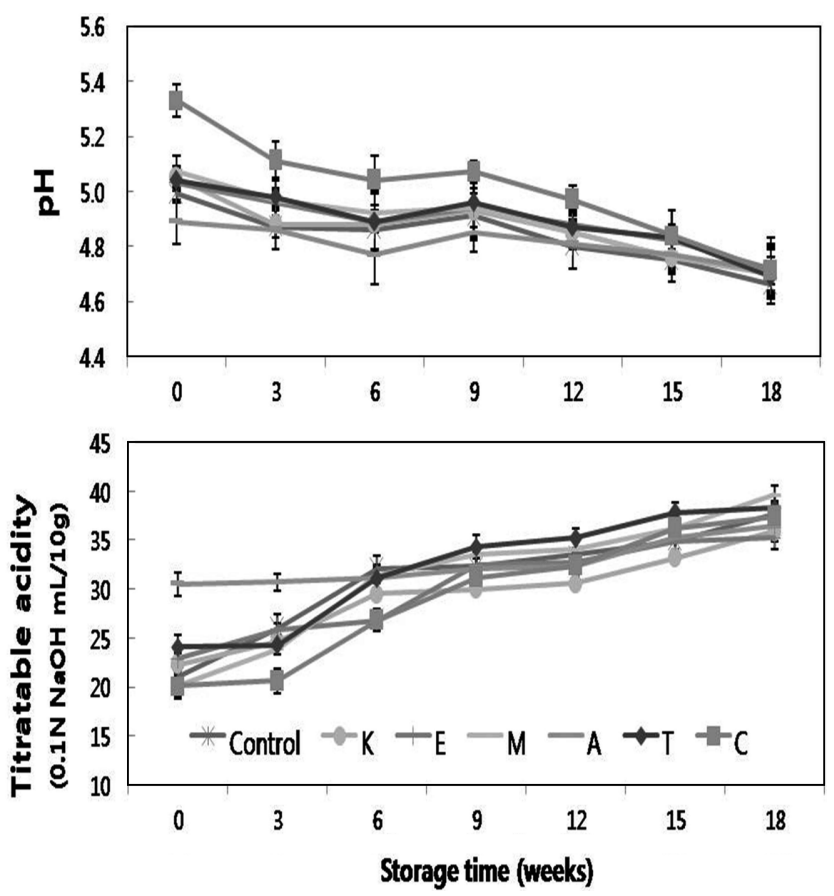

Fig. 5 Changes in $\mathrm{pH}$ and titratable acidity of ssamjang during storage at $30^{\circ} \mathrm{C}$.

9주에 근소하게 증가하나 그 이후 서서히 저하되었다. 또한 부 원료를 첨가한 구보다는 대조구의 $\mathrm{pH}$ 가 낮은 수준이었고 시판 제품에서 $\mathrm{pH}$ 의 저하는 심하였다. 적정산도는 $\mathrm{pH}$ 가 저하됨에 따 라 저장 중에 점진적으로 증가되었으며, 산도의 증가는 겨자와 울금 첨가구에서 심하였으나 알코올과 $\mathrm{K}$-sorbate 첨가구에서 적 었다. 적정산도의 변화가 미생물의 대사 작용에 의한 유기산의 생성에 기인한다고 볼 때 겨자나 울금보다는 K-sorbate나 알코 올의 첨가가 유기산 생산균의 생육 조절에는 효과적일 것으로 생각되었다. 저장중 산도의 증가는 원료 된장을 달리한 쌈장 $(\mathrm{Kim}$ 등, 1999a), 감마선을 조사한 쌈장(Kim 등, 2000a), 60$70^{\circ} \mathrm{C}$ 에서 20 분간 살균 처리한 쌈장 $(\mathrm{Kim}$ 등, $2005 \mathrm{~b})$ 등의 보고 에서도 유사한 경향이었다.

환원당과 알코올. 쌈장의 환원당은 Fig. 6과 같이 울금 첨가구 를 제외하고는 저장 9 주까지 증가하다가 그 이후에 감소하여 18 주 저장 후에 K-sorbate와 알코올, 겨자 첨가구는 21.39$21.66 \%$ 이었으나 울금 첨가구는 $18.49 \%$ 로 낮았다. 한편 시판 쌈 장의 환원당은 9.84-26.39\%로 제품별로 차이가 심하였고(Seo 등, 2001), $\mathrm{Kim}$ 등(1999a)의 된장 종류를 달리하여 제조한 쌈 장의 경우 환원당 함량이 저장 30 일에 $12.32-15.89 \%$ 에 제일 높았고 그 이후에는 감소하였다고 보고하여 본 실험과는 차이 가 있었다.

알코올은 시판 제품을 제외하고는 저장 중에 증가되어 12-15 주에 최고에 달하였으며 매실즙과 울금 첨가구는 저장 3 주에 급 격히 증가되었다. 반면 대조구는 저장 중에 서서히 증가되었으 며 K-sorbate와 겨자 첨가구의 변화는 거의 없었다. 쌈장 저장 중 알코올의 증가는 환원당의 감소 및 가스 생성과 상관성이 있 었으나 효모수의 증가와는 일치하지 않아 효모 종류별로 알코 올 생성능에서 차이가 있는 것으로 판단되었다. 또한 고추장은 저장 중에 알코올 생성이 미미하였던 보고(Kim과 Kwon, 2001;
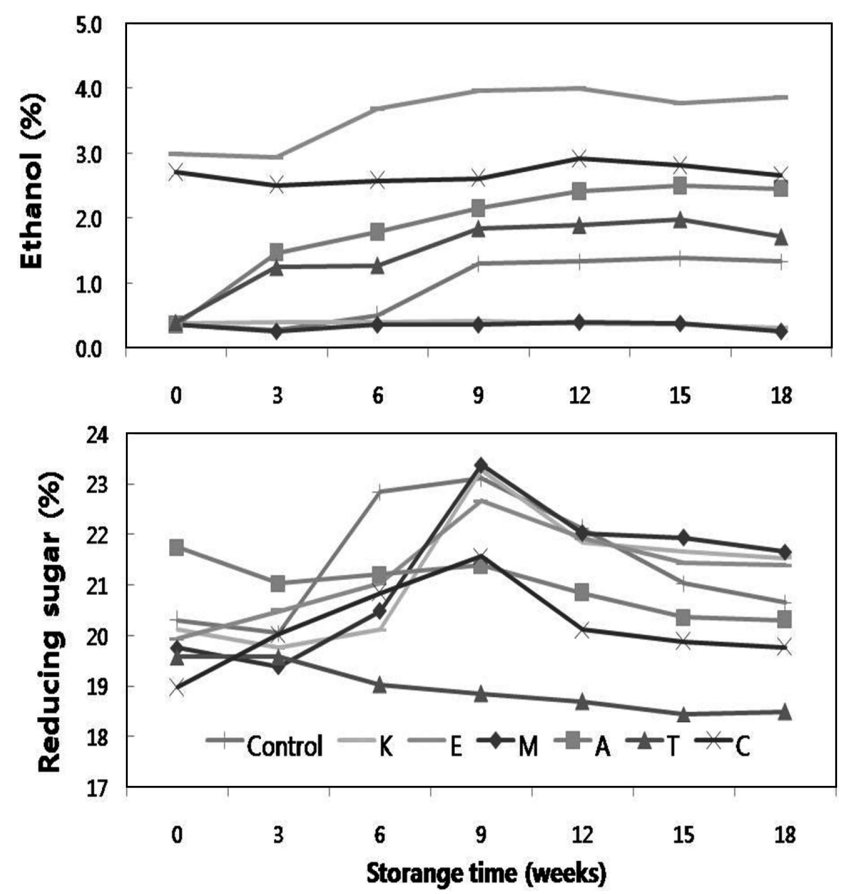

Fig. 6 Changes in reducing sugar and ethanol content of ssamjang during storage at $30^{\circ} \mathrm{C}$.
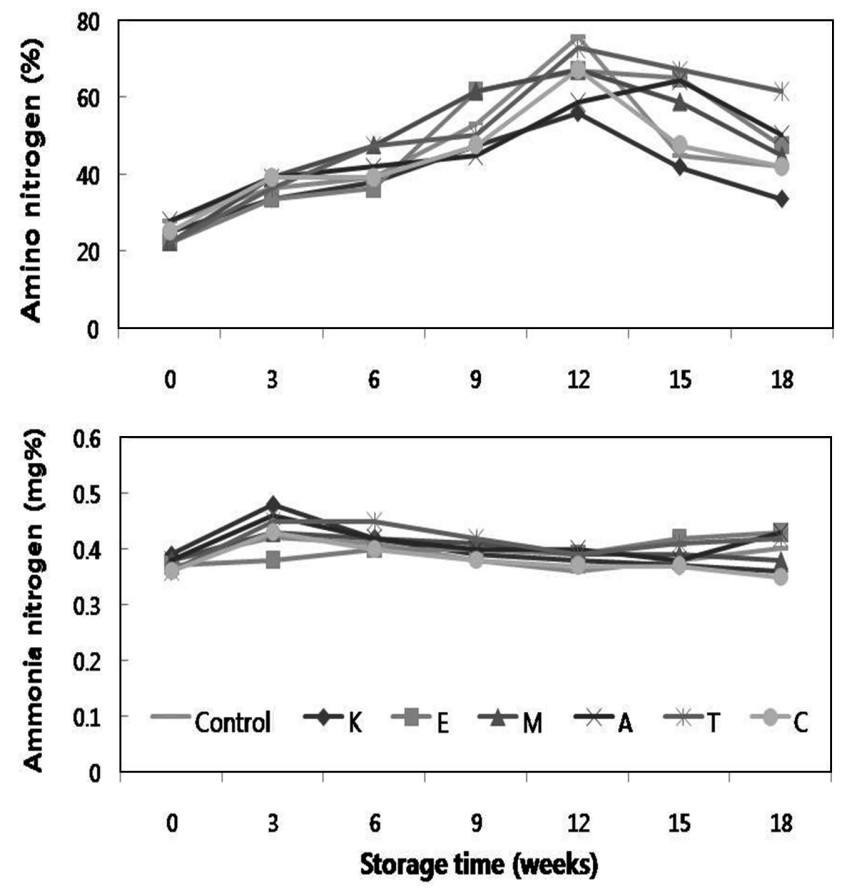

Fig. 7 Changes in amino- and ammonia-type nitrogen content of ssamjang during storage at $30^{\circ} \mathrm{C}$.

Han과 Kim, 2008)와 차이가 있었는데 이는 쌈장을 제조하는 과 정에서 된장과 고추장, 물엿 이외에 부원료를 혼합한 관계로 저 장 중에 다시 미생물에 의한 발효가 진행되는 것으로 생각되었다. 질소성분. 질소성분의 변화는 Fig. 7 과 같이 아미노산성 질소의 
Table 4 Sensory evaluation of ssamjang

\begin{tabular}{|c|c|c|c|c|}
\hline Ssamjang & Taste & Color & Flavor & Overall acceptability \\
\hline Control & $4.20 \pm 1.45^{\mathrm{a})}$ & $4.50 \pm 0.83^{\mathrm{ab})}$ & $4.65 \pm 1.27^{\mathrm{ab})}$ & $4.40 \pm 1.31^{a)}$ \\
\hline $\mathrm{K}$ & $4.40 \pm 1.05^{\mathrm{a})}$ & $4.35 \pm 1.27^{\mathrm{b})}$ & $3.90 \pm 1.45^{\mathrm{b})}$ & $4.40 \pm 0.94^{a)}$ \\
\hline $\mathrm{E}$ & $4.15 \pm 1.47^{a)}$ & $5.10 \pm 1.25^{\mathrm{ab})}$ & $4.10 \pm 1.37^{\mathrm{b})}$ & $4.60 \pm 1.27^{\mathrm{a})}$ \\
\hline M & $4.80 \pm 1.28^{\mathrm{a})}$ & $5.25 \pm 1.02^{\mathrm{a})}$ & $5.30 \pm 1.03^{\mathrm{a})}$ & $4.95 \pm 0.76^{\mathrm{a})}$ \\
\hline A & $4.45 \pm 1.61^{\mathrm{a})}$ & $5.30 \pm 1.30^{\mathrm{a})}$ & $4.60 \pm 1.05^{\mathrm{ab})}$ & $4.80 \pm 1.36^{\mathrm{a})}$ \\
\hline $\mathrm{T}$ & $4.75 \pm 0.97^{\mathrm{a})}$ & $4.70 \pm 1.03^{\mathrm{ab})}$ & $4.75 \pm 1.16^{\mathrm{ab})}$ & $4.65 \pm 0.81^{a)}$ \\
\hline $\mathrm{C}$ & $4.60 \pm 1.23^{\mathrm{a})}$ & $5.30 \pm 1.34^{\mathrm{a})}$ & $4.20 \pm 1.32^{\mathrm{b})}$ & $4.90 \pm 1.25^{\mathrm{a})}$ \\
\hline
\end{tabular}

${ }^{1)}$ See footnotes in Table 1.

${ }^{2)}$ Values are mean $\pm \mathrm{SD}$

${ }^{3)}$ Means with the same letter in column are not significantly different by Duncans multiple range test $(p<0.05)$

경우 저장 3 주에 증가하나 그 이후에는 서서히 감소하다가 저 장 후기에 다시 증가하는 경향을 보였다. 시험구간에는 저장 후 기에 시판 쌈장과 $\mathrm{K}$-sorbate, 겨자 첨가구에서 아미노산성 질소 량이 적은 편이었다. 한편 암모니아성 질소는 저장 12 주까지 증 가하다가 그 이후에 감소하는 경향을 보여 아미노산성 질소의 변화와는 다른 양상을 보였다. 시험구간에는 특징적인 차이는 없으나 K-sorbate와 겨자 첨가구, 시판 쌈장에서 저장 후기의 변화가 적은 편이었다. 한편 된장의 종류를 달리하여 제조한 쌈 장은 저장 중에 아미노산성 질소가 급격히 증가되었고 $(\mathrm{Kim}$ 등, $1999 \mathrm{a} ; 2005 \mathrm{a}), 60-70^{\circ} \mathrm{C}$ 에서 20 분간 살균처리한 상업적 쌈장도 저장 6주까지 아미노산성 질소가 현저하게 증가되었다고 보고 (Kim 등, 2005b)된 바 있다. 따라서 쌈장은 가열살균 처리나 미 생물의 생육을 조절할 수 있는 보존료나 부원료를 첨가하지 않 으면 저장 중에 이상발효에 의한 제품의 품질저하 가능성이 높 은 것으로 판단되었다.

관능검사. 부원료의 종류를 달리하여 제조한 쌈장을 관능 평가 한 결과는 Table 4 와 같이 맛의 경우 겨자와 울금, 매실즙 첨 가구 등이 양호하였으나 나머지 시험구간의 차이는 없었다. 색 은 시판 쌈장과 매실즙, 겨자 첨가구가 $\mathrm{K}$-sorbate 첨가구에 비 하여 양호하였다 $(p<0.05)$. 향기는 겨자 첨가구가 $\mathrm{K}$-sorbate 첨 가구나 알코올 첨가구에 비하여 양호하여 $(p<0.05)$, 전체적인 기 호도에서 겨자와 매실즙, 울금, 알코올 첨가구가 양호하였다. 시 판 쌈장과 비교하면 겨자 첨가가 유의적인 차이는 없으나 양호 하였고 다음으로 매실즙 첨가구 순으로 좋았다. 따라서 시판 쌈 장도 기본적인 재료 이외에 여러 가지 부원료를 혼합하는 것이 효과적인 것으로 판단되었다.

\section{초 록}

부원료 첨가를 달리하여 제조한 쌈장을 포장하여 $30^{\circ} \mathrm{C}$ 에서 18 주간 저장하면서 저장중 이화학적인 특성 변화를 검토하였다. 쌈장의 색은 L-와 a-, b-값 모두 저장중 서서히 감소하였으며, $\Delta \mathrm{E}$ 값의 변화는 대조구에서 심하였다. 쌈장 저장중의 가스 생성 은 K-sorbate와 알코올, 겨자 첨가로 억제되었다. 저장중 쌈장 의 효모수는 6 주에 급격히 증가하였으나 겨자와 알코올, $\mathrm{K}-$ sorbate 첨가구에서 적었고, 매실즙과 울금 첨가구에서 많아 이 들 첨가구에서 효모수의 증가가 가스 생성의 직접적인 원인이 되었다. 산화환원전위 $(\mathrm{ORP})$ 는 저장 6주, 수분활성도는 저장 12 주까지 저하되었으나 그 이후에는 근소한 증가를 보였다. 적정
산도는 저장 중에 $\mathrm{pH}$ 의 저하에 따라 증가되었으며, K-sorbate 와 알코올 첨가구에서 적었다. 환원당은 울금 첨가구를 제외하 고는 저장 9주까지 증가되었으며, 알코올은 매실즙과 울금 첨 가구는 저장 15 주까지 증가되었다. 쌈장은 유의적인 차이는 없 으나 맛과 향기에서 겨자와 울금 첨가구가 양호하였고 전체적 인 기호도에서 겨자 첨가구가 양호한 것으로 판단되었다.

\section{참고문헌}

Choi HY (2009) Antimicrobial activity of Ulgeum (Curcuma longa L.) extract and its microbiological and sensory characteristic effects in processed foods. Korean J Food Cookery Sci 25, 350-6.

Difco Laboratories (1984) Dehydrated culture media and reagents for microbiology. In Difco Manual (10th ed.), pp. 1064-5. Difco, Detroit, Michigan, USA.

Han SM and Kim DH (2008) Effect of combined use of anti-microbial materials on storage of low salted kochujang. J Korean Soc Biol Chem 51, 281-7.

Institute of Miso Technologists (1968) Official methods of miso analysis. pp. 1-34. Changpeung-dang, Tokyo, Japan.

James MJ (2000) Modern Food Microbiology (6th ed.), pp. 45-7. APAC, Nevada, USA.

Kang IH (1986) The History of Korea Food Pattern (in Korean). p. 148, Samyoungsa, Seoul, Korea.

Kim DH, Ahn HJ, Yook HS, and Kim MJ (2000a) Ouality properties of gamma irradiated samjang, seasoned soybean paste during storage. Korean J Food Sci Technol 32, 396-401.

Kim DH and Kwon YM (2001) Effect of storage conditions on the microbiological and physicochemical characteristics of traditional kochujang. Korean J Food Sci Technol 33, 589-95.

Kim EL and Kang SC (2007) Quality evaluation by the addition of pine needle and Artemisia princeps extracts in vinegared kochujang. J Korean Soc Appl Biol Chem 50, 167-77.

Kim GT, Hwang YI, Lim SI, and Lee DS (2000b) Carbon dioxide production and quality changes in Korean fermented soybean paste and hot peppersoybean paste. J Korean Soc Food Sci Nutr 29, 807-13.

Kim HL, Lee TS, Noh BS, and Park JS (1998a) Characteristics of samjangs prepared with different doenjangs as a main material. Korean J Food Sci Technol 30, 54-61.

Kim HL, Lee TS, Noh BS, and Park JS (1999a) Characteristics of the stored samjangs with different doenjangs. Korean J Food Sci Technol 31, 3644.

Kim JS, Choi SH, Lee SD, Lee KH, and Oh MJ (1999b) Quality changes of sterilized soybean paste during its storage. J Korean Soc Food Sci Nutr 28, 1069-75.

Kim MS, Oh JA, Shin DH, and Han MS (1998b) Fermentation properties of irradiated kochujang. Korean J Food Sci Technol 30, 934-40. 
Kim ND (1996) Study on the browning and its inhibition in soybean paste(doenjang). $\mathrm{PhD}$ Thesis, Konkuk University, Seoul, Korea.

Kim YK, Kim SJ, and Chang KS (2005a) Browning characteristics of ssamjang during storage. J Korean Soc Food Sci Nutr 34, 529-37.

Kim YK, Kim SJ, Han MS, Chang YI, and Chang KS (2005b) Physicochemical changes of commercial ssamjang during storage. Korean $J$ Food Sci Technol 37, 389-96.

Kwak EJ and Lim SI (2003) Effect of addition time of antibrowning agents on browning and fermentation characteristics in doenjang. J Korean Soc Food Sci Nutr 32, 495-500.

Kwon DJ, Kim YJ, Kim HJ, Hong SS, and Kim HK (1998) Changes of color in doenjang by different browning factors. Korean J Food Sci Technol
30, 1000-5.

Lee KI, Moon RJ, Lee SJ, and Park KY (2001) The quality assessment of doenjang added with Japanese apricot, garlic and ginger, and samjang. Korean J Food Cookery Sci 17, 472-7.

Martin EP (1965) Use of acid, rose bengal, and streptomycin in the plate method for estimating soil fungi. Soil Sci 69, 215-32.

Seo JS, Lee TS, and Shin DB (2001) The study on the characteristics of commercial samjangs. J Korean Soc Food Sci Nutr 30, 382-7.

Thomas YD, Lulvwes WJ, and Kraft AA (1981) A convenient surface plate method for bacteriological examination of poultry. J Food Sci 46, 19512. 